\title{
THE VARIATION OF BALINESE CULTURAL TERMS IN BANGLI MEDIA TOURISM PROMOTION
}

\author{
Kadek Ayu Ekasani, I Gusti Ayu Agung Dian Susanthi, Ni Luh Gede \\ Liswahyuningsih. STP Bali Internasional, Warmadewa University, IKIP PGRI \\ Bali \\ ayuekasani@gmail.com,junk_gek@yahoo.com, lis_mymail@yahoo.com
}

\begin{abstract}
There are so many tourism texts in English, so that ranslation study and tourism is very close to each other. Bali, as tourist destination is popular with its culture and tradition, Bali has eight regencies which are very interesting to visit. One of them is Bangli which is very popular with tourism destination. It has its own media to introduce its culture, tradition, etc. This writing deals with the process of meaning transfer in Balinese cultural term in Bangli Media Tourism Promotion.. The data used in this study is taken from Bangli's booklet of tourism promotion which represent the Balinese cuture and tradition. The componential analysis which relates to semantics theory is used in this study, this theory helps to understand about the meaning of the Balinese cultural terms. The theories applied in this study are semantic components by Larson (1998) and the intercultural communication by Scollon (1995). The analyzed data is presented informally (in the form of words and sentences) and formally (the used of symbol). There are some cultural terms which discussed in this study: kulkul_Balinese bell; banjar-community group; pelinggihshrine; kain putih—white fabrics; lontar-old manuscript; purusamale; pradana-female.
\end{abstract}

Keywords: Balinese cultural terms, meaning, componential analysis

\section{INTRODUCTION}

Tourism has become an important sector that has an impact on development of country economy. The main benefits of tourism are income creation and generation of jobs. For many regions and countries it is the most important source of welfare, specially in Bali island as one of popular tourism destinaton for tourists in Indonesia. Bali has a perfect holiday destination and exciting amusements, that can make tourists really enjoy to visit Bali. In order to maintain the quantity of tourists in Bali, the government through Goverment Tourism Office must be held some promotion in developing the tourism sector in every regency in Bali. One of regencies in Bali that held some tourism promotion is Bangli regency.

Bangli is one of the most enchanting area in Bali has a good weather and climate. Among eight regencies and one city in Bali, Bangli is the only regency without a coastline area. However, Bangli owns the biggest lake in Bali, the Batur 
Lake, which functions as a source of water for a large part of the farmland in south Bali. Bangli has some of the most traditional communities in Bali, including the Bali Aga village of Trunyan, renowned for its mortuary rituals. Unlike other Balinese who cremate the dead in an elaborated ceremonies, the inhabitants of Trunyan leave the dead bodies above the ground in sacred cemetery. As the sites of one of Bali's famous kingdoms, Bangli has a number of ancient royal sites, including the temple of Pura Kehen, which is located on the north of the laud-back town of Bangli. Bangli is also home for the one of Bali's most important temples, the Pura Batur, an impressive ancient complex, devoted to the Goddess of water, who ensure the rice fields are always irrigated.

To promote all of the tourism objects in Bangli, Bangli Government Cultural and Tourism Office published the promotion media booklet to inform all the tourism objects to visitors who come in Bangli. The culture and tradition also become a part of tourism in Bali. This is the reason why the government also introduce some of the Balinese culture in its media promotion to attract the tourists to come to Bali, specially in Bangli. However the use of Balinese cultural terms are sometime difficult to understand with the visitors so this study will focuss on describing some of Balinese cultural terms that are used in Bangli media tourism promotion through the componential analysis of semantics.

Based on the above explanation, there are three problems that need to be formulated, such as the following:

1. What kind of Balinese cultural terms discussed?

2. How does the semantics explain about the terms?

3. How does the componential analysis work on its explanation?

The words in particular noun phrases representing the Balinese cultural terms and the analysis of its meaning based on the semantic components.

\section{THEORIES USED IN THIS WRITING}

\subsection{Cultural terms}

Scollon (1995) in her book entitled "intercultural communication" states that in studies of intercultural communication our concern is not with high culture but with anthropological culture. When we use the word "culture" in this anthropological sense, we mean to say that culture is any of customs, worldview, language, kinship system, social organization and other taken for granted day to day practices of people which set that group apart as distinctive group. By using the anthropological sense of the word "culture" we mean to consider any aspect of the ideas, communications, or behaviors of a group people which gives them a distinctive identity and which is used to organize their internal sense of cohesion and membership. So that cultural terms are the expression of certain group or community to express their idea, concepts principles, etc, this built up by their own culture and tradition in their life.

\subsection{The types of cultural words}

Newmark (1998) categorized the cultural words into five, as follows:

1) Ecology. It is a geofraphical feature that can be normally distinguished from other cultural terms in that they are usually value-free, politically and commercially. It includes Flora, Fauna, mountain, river, natural conditions. 
2) Material Culture. It is the culture specific element that includes clothing, food, houses and towns, transportation, tools and equipments.

3) Social culture-work and leisure such as the names of music, games or dance that is typical in certain areas.

4) Organizations, customs, activities, procedures and concept.

5) Gesture and habits. In this case, there is a distinction between description and function which can be made where necessary in ambiguous cases.

Scollon (1995) states tht the aspect of culture which are most significant for the undersanding system of discourse and which have been shown to be major factors in itercultural communicationare as follows:

1) Ideology : history and worldview, which includes beliefs, values and religion

2) Socialization:

a. Education, enculturation, acculturation

b. Primary and secondary socialization

c. Theories of the person and of learning

3) Forms of discourse:

a. Function of language: information and relationship; negotiation and ratification; group of harmony and individual welfare

b. Non-verbal communications

1) kinesics : the movement of our bodies

2) Proxemics : the use of space

3) Concepts of time

4) Face systems : social organization, which includes: kinship, the concept of the self, in group-out group relationship, Gemeinschaft and geselschaft (community and society).

\subsection{Componential Analysis Theory}

The componential analysis theory applied in this study based on Larson (1998) and Newmark (1998). The kinds componential analysis can be seen as in below:

Balinese architecture term : Merajan which usually translated into house of temple on some texts book. However some particular meaning loss on its translation. It can be seen on this following componential analysis

$\begin{array}{lcc} & \text { Merajan (Noun) } & \text { House of temple (N) } \\ \text { Temple } & + & + \\ \text { Located in a noble house } & + & -/+ \\ \text { A temple for the family member } & + & + \\ \text { Social status } & + & -\end{array}$

From the above description Merajan is usually translated into house of temple on some texts book, however house of temple does not represent the social status of the owner

\subsection{Media Promotion}

There are many types of media promotion that people used (Muryanto, 2010):

1) Flyer: is a leaf let that consists of only one sheet. Mostly the size not more than A5 or $14.8 \mathrm{~cm} \times 24 \mathrm{~cm}$. 
2) Poster: Also called plaque, which is includes image, graphic design and words put together in big size of letter or $24 x$ 36inches.

3) Billboard: is a poster with very large size and mostly, people (marketers) put it in high position and it is easy to see by other people (customers).

4) Banner: is very huge poster, the size can be two to four times of poster or even greater.

5) Pamphlet: Often referred to as a brochure, which is not a periodical publication, it may consist of one or a small number of pages. It is not related to another issue, completed in a single publication.

6) Booklet: It is consists of several pages and often have a cover, title page, bound both simple to use staples or it could be bound with a decorative ring for example using.

7) Catalogue: a booklet with complete information.

8) Leaflet: Usually consists of one page with two mould faces.

9) Flyer: Only one face of the mold. Flyers are short information, which are separated via air plane or vehicle borne away in public places.

10) Business Card: Usually business card size is not more than $9 \times 6 \mathrm{~cm}$. Sometimes called Name Card.

11) Internet: Internet is a program in computer that connected in all over the world, and people can use to do many things, such as search for information, advertising or buy some products. Internet is a huge networking that connected with other small network in a computer by using network from telephone, satellite or other telecommunication systems (Hardyani, Mamesah, \& Dimaz, 2011).

12) Website: Website is a way to provide some information, promote or sell some product and presenting yourself in internet (Jogjacamp, 2005).

\subsection{Equivalence}

The equivalence theory is very interesting to be discussed in translation study Nida (1964:159) proposed two terms for the types of equivalence. They are formal and dynamic equivalence. Formal equivalence focuses its attention on the message itself, in both form and content. The message in receptor language should match as closely as possible the different elements in the source language. Formal equivalence is also called gloss translation, in which the translator attempts to produce as literally and meaningfully as possible the form and content of the original text. Meanwhile dynamic equivalence is based on the principle of equivalent effect. This type of equivalence aims at complete naturalness of expression and tries to relate the receptor modes of behavior relevant within the context of its culture.

\section{MATERIAL AND METHOD}

The data used in this study is taken from Bangli's booklet of tourism promotion which represent the Balinese cuture and tradition. In the data collection, the library research method was conducted through attentive observation method proposed by Sudaryanto (2015). The observation method is conducted by observing thoroughly the data which contain Balinese cultural terms. The data was analyzed according to the classification of problems which occur in transferirng the meaning of Balinese cultural terms. This study is used 
qualitative method in analyzing the data that proposed by Djajasudarma (1993). In terms of qualitative method, the data were analyzed descriptively based on the problems and analyzed based theory applied in this study. Firstly, the collected data was grouped according to the Balinese cultural terms, then the data was analyzed semantically by using semantic component theory proposed by Larson (1998) . The analyzed data is presented informally (in the form of words and sentences) and formally (the used of symbol) (Sudaryanto, 2015).

\section{DISCUSSION}

Data 1

SL : Kulkul

TL: Balinese Bell

The analysis of meaning can be seen as in below:

Traditional instrument

Made of bamboo or wood

It is used for Balinese activities

Ritual tool

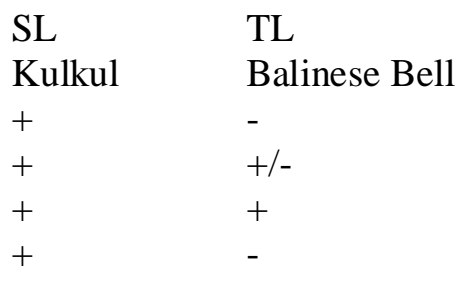

From the data (1), kulkul is a traditional communication for Balinese society, it is usually made of bamboo or wood. When it is sounded, it means that there are Balinese activities that have to be undertaken, such as meeting, mutual cooperation, and other social activities like occurence of emergency such as fire, theft, riots, and also as the information on villager's death. Besides kulkul is sounded also during big ritual ceremonies so it is placed in temple. Kulkul is translated to Balinese bell, it can be seen on the componential analysis that the English translation (Balinese bell) does not represent all categories which described on the analysis. Kulkul contains the meaning of traditional instrument since it is inherited from the tradition of Balinese society which was used to give sign of social activities. In the past, there were not any modern communication tools, like a phone that we have today, so the previous generation of Balinese people use kulkul to give sign of something to other people. Meanwhile, the Balinese bell can be modern one (-) since it doesn't contain the traditional meaning. Kulkul is placed also in temple as a ritual tool and sounded to give sign for Hindu's people there is a big ceremony in that temple. In TL, the Baliness bell doesn't contain the ritual tool (-). Besides, kulkul is made of bamboo or wood while the Balinese bell can be made of other materials such as iron. However, in this case the translator tries to use the closest equivalent term in the TL since kulkul and Balinese bell can be sounded to give sign of Balinese activities. 


\section{Data 2}

\section{SL: Banjar}

\section{TL: Community Group}

The analysis of meaning can be seen as in below:

$\begin{array}{lll} & \text { SL } & \text { TL } \\ & \text { Banjar } & \text { Community Group } \\ \text { Unity of the legal community in Bali } & + & +/- \\ \text { Legal community for Balinese society } & + & +/- \\ \text { Social activities } & + & +/- \\ \text { Traditional/ religious activities } & + & +/-\end{array}$

From data (2), the term Banjar is Balinese term for groups in Bali where the Balinese people live and run social activity and traditional/ religious ceremony together. Each village in Bali is divided into one or more banjar, a cooperative association of neighbors who assist each other in the preparation and financing of costly events. Here the term banjar contains the meaning of legal community in Bali which binds its member based on Balinese culture and tradition. As a legal community in Bali, the banjar is the basic government unit of the village and it helps in disseminating information and policy. The banjar serves simultaneously as town council, department of environment and sanitationi. The term banjar is translated into community group. In the TL, it is seen that, some categories are not transferred into English. Community group does not represent legal community for Balinese society, it can be meant common group as well. However, in this case the translator tries to use the closest equivalent term in the TL.

\section{Data 3}

SL: Pelinggih

\section{TL: Shrine}

Thing

Balinese style/decoration

$\begin{array}{ll}\text { SL } & \text { TL } \\ \text { Pelinggih } & \text { Shrine } \\ + & + \\ + & -\end{array}$

The term pelinggih in Bali has specific and traditional style and decoration, which is noted (+), it is tanslated into shrine. In this case the category of traditional style and decoration of Bali does not occur in the TL. Pelinggih usually made in Bali and it is made by Balinese artist, so that it has Balinese style and decoration, shrine might be made in different decoration or style, so that it can be noted (-), since it does not contain the meaning of Balinese style and decoration. However, in this case the translator tries to use the closest equivalent term in the TL. 


\section{Data 4}

\section{SL: Kain Putih}

\section{TL: White Fabrics}

Thing

Used in Balinese activities

$\begin{array}{ll}\text { SL } & \text { TL } \\ \text { Kain Putih } & \text { White Fabrics } \\ + & + \\ + & +\end{array}$

Based on above analysis, the data (4) shows that kain putih which is translated into white fabrics in the TL contains the same meaning, so that all categories in the TL can be noted by using (+). In the Balinese activities such as sacred activities the kain putih (white fabrics) is generally used.

\section{Data 5}

SL : Lontar

\section{TL : Old Manuscripts}

Thing

Old

Made of leaves

$\begin{array}{ll}\text { SL } & \text { TL } \\ \text { Lontar } & \text { Old Manuscript } \\ + & + \\ +/- & + \\ + & +/-\end{array}$

From the above data (4) shows that Lontar contains the meaning thing $(+)$ and Lontar itself can be old or new so that noted by $(+/-)$, since some people still maintain to write Balinese alphabet by using Lontar itself. In the TL (old manuscript) contains the meaning thing $(+)$ and old $(+)$. Lontar is a kind of falmleaf where the traditional Balinese usually write message on it, but when it is translated into old manuscrift, the meaning of the material of falmleaves is lost since old manuscript can be written on other materials. However in this case the translator tries to find the closest term in the TL by using the old manuscript.

\section{Data 6}

SL : Purusa

TL: Male

Sex

Responsibility

$\begin{array}{ll}\text { SL } & \text { TL } \\ \text { Purusa } & \text { Male } \\ +/- & + \\ + & +/-\end{array}$

From the above data (5) shows that purusa contains the meaning of responsibility (+) since the term purusa is not only about sex but more about gender in Balinese family. The meaning of responsibility in term of purusa is about responsibility to the family life which can be handled by both man and woman. Balinese tradition is patrilineal which means that the male child takes responsibility of the family life and the marriage woman will follow her husband. But in the modern life like nowadays, the female child can take the responsibility and her husband will follow her to the woman's family which is called as nyentana. In that case, the female child will be the purusa in her family. Meanwhile, when the term purusa is translated into male so the meaning of responsibility is disappeared since the term male only contains the meaning of 
sex. However in this case the translator tries to find the closest term in the TL by using term male because generally the responsibility of purusa comes to the male child of the family.

\section{Data 7}

\section{SL : Predana}

TL: Female

Sex

Responsibility

$\begin{array}{ll}\text { SL } & \text { TL } \\ \text { Predana } & \text { Female } \\ +/- & + \\ + & +/-\end{array}$

Same as the data (5), the data (6) also shows that predana contains the meaning of responsibility (+) because the term predana is not only about sex but also about gender in Balinese family. The woman who has married, she has the responsibility as a pradana in her husband's family. The responsibility of pradana will be changed into purusa since the woman in her own family take a man to be her husband in woman's family. This marriage is called nyentana. Here, the term of pradana is translated into female in TL and has the meaning of sex. However in this case the translator tries to find the closest term in the TL also by using term female because generally the responsibility of pradana comes to the female child of the family.

\section{CONCLUSION}

There are some cultural terms which discussed namely: There are some cultural terms which discussed in this study: kulkul-Balinese bell; banjarcommunity group; pelinggih-shrine; kain putih-white fabrics; lontar-old manuscript; purusa-male; pradana-female. There are some information which loss in the English, since there are no specific terms in the English. The componential analysis on semantics study helps to understand about those cultural terms on this writing.

\section{REFERENCES}

Bangli Government Cultural and Tourism Office. 2015. Bangli Regency Tourist Information. Bangli.

Djajasudarma, T. Fatimah. 1993. Metode Linguistik: Ancangan Metode Penelitian dan Kajian. Bandung: Eresco

Larson, Mildred L. 1998. A Guide to Cross-Language Equivalence. Boston: University Press of America, Inc

of America

1998. Meaning-Based Translation. Boston: University Press

Muryanto, Andy Suhaimi. 2010. Types of Media Promotions (2). Kecakot

Journal of Business on Hospitality and Tourism 
Newmark, Peter. 1998. Approaches to Translation. Oxford: Pergamon.

Scollon, Ron. \& Scollon Suzanne Wong. 1995. Intercultural Communication: A Approach discourse. Massachusetts: Basil Blackwell Inc.

Sudaryanto. 2015. Metode dan Aneka Teknik Analisis Bahasa. Yogyakarta : Sanata Dharma University Press 